\title{
Revitalizing Cooperative Programmes Activities for Active Participation of Rural Women Towards Enhancing Community Development in Nigeria
}

\author{
Dr. Blessing Chinyere Elekwa \\ Dept. Of Adult Education, Faculty Of Education Nnamdi Azikiwe University, Awka. \\ DOI: 10.29322/IJSRP.10.12.2020.p10806 \\ http://dx.doi.org/10.29322/IJSRP.10.12.2020.p10806
}

\begin{abstract}
This study focused on revitalizing cooperative programmes activities for active participation of rural women towards enhancing community development. The need for the study arose as a result of less access to education, unemployment, poverty, low income status, burden of child bearing and lack of adequate information on cooperative programmes experienced by rural women in Nigeria. However, these cooperative programmes which includes Agricultural cooperative, thrift and credit cooperative, cooperative education programme, as well as, leadership training activity, will enhance the rural women's potentials, improve their standard of living and equip them to deal with the dynamism of the modern society. Also, the study focused on the concept of rural women, participation, cooperative programme activities and community development respectively. Furthermore, strategies for revitalizing rural women's participation in cooperative programmes for active participation of rural women towards enhancing community development, factors that hinder rural women from active participation in cooperative programmes and the way forward, were discussed.
\end{abstract}

Index Terms- Cooperative programmes, Rural women, Participation, and Community Development.

\section{INTRODUCTION}

$\mathrm{R}$ ural women are active agents of economic and social change who play vital roles in the development of the nation. The importance of rural women in taking care of their families and communities to realize food security, increase income and improve their quality of life cannot be overemphasized. According to Okeme \& Akpama (2018), they noted that women in the rural areas are known for their hard work in farm work, they make foods available and cheaper, so as to reduce hunger, malnutrition, extreme poverty and build a healthy generation.

Unfortunately, in the rural areas, especially in developing countries like Nigeria, rural women are the poorest and more vulnerable among the poor, yet, they are made up of about $43 \%$ of the agricultural work force as reported by FAO (2011). Furthermore, the rural women are regarded as effective farmers just like men despite their low productivity output which may be attributed to less access to information, resources, labour and financial support. Aside this, successive governments in Nigeria had initiated programmes in the past for the betterment of the rural dwellers, especially the rural women. Such programmes include National Poverty Reduction Programme/Community Based Poverty Reduction Agencies, Peoples Bank, National Directorate of Employment, Family Support Programme and Better Life for Rural Women, You Win Programme and Vision 2020, among others.

These programmes which were established for the integration of rural development, reduction of poverty, enhancement of the status of rural dwellers and improvement of the overall standard of living, had little or no effect on the beneficiaries. However,Ekom (2002) maintained that development programmes has always been the top down approach where the designing and implementation are carried out at the government circle without involving the beneficiaries at the decision making stage. This maybe the reason, Ekesionye \& Okolo (2012), noted that majority of the rural women are not beneficiaries of the different government programmes, even though these women are engaged in income generating activities that require financial assistance. To bring development nearer to the rural dwellers, especially the rural women there is need to help them out of their poverty state by collective pursuance of economic interest and as well reduce the economic effects of Covid-19 pandemic. Such situation requires expedient actions by governmental and non-governmental agencies, policy makers, community leaders in boosting the rural women's sources of income through cooperative programmes.

In this study, cooperative programme activities are entrepreneurial activities that motivate people to collectively join their efforts and resources together and engage in any meaningful and productive ventures that will enhance their status. According to Dogaruwa (2008) cooperatives are democratic, communitybased and resilient association that involves participation. They are essential ingredients for improving the living conditions of people, especially the rural women. Similarly, AFCD (2019), stated that a cooperative is an independent association of persons that voluntarily joined together to meet their socio-economic, cultural needs and aspirations through an enterprise that is democratically controlled. This means that cooperative programme activities offer a sense of belonging, create employment opportunities, increase food production, reduce poverty and illiteracy as well as, increase the income level of the rural women. These cooperative programme activities include Agricultural cooperative, thrift and credit cooperative, cooperative education programme, as well as leadership training activities. 
Regrettably, Maleko \& Msuya (2015) noted that, these cooperative programme activities have not been given the required attention they deserve in the community in reducing the scourge of poverty among the poor rural women. Perhaps, it may be due to the fact that these rural women do not seem to appreciate these cooperative opportunities open to them and that makes them to have little or no interest in these cooperative programmes (Ikonne $\&$ Duru, 2015). In order to sustain their interest on cooperative programme activities, these rural women should have access to relevant, timely information and knowledge about cooperative programmes and resources that can assist them to participate actively and contribute meaningfully to the general development of the society. When these rural women participate actively in cooperative programme activities, their socio-economic life will change and opportunities for self-accomplishment, economic growth, modification of public opinion about them and more especially their total wellbeing will be enhanced (Uhegbu, Unagha and Amaechi 2017).

Participation of women as observed by Deji (2007) is inevitably significant to the success and sustainability of community development programmes, because they are the majority of the workforce in the rural areas. This shows that participation, not only empowers women, but also brings development and growth. In this regard, Organization of Economic Cooperation and Development (2012) stated that strengthening the rural women's ability to participate in work force is seen as a means of challenging scourge of poverty and issues of economic sustainability. Sustainable economic development and growth in any nation can be achieved through rural transformation and empowerment of rural dwellers, especially the rural women. It is important to note that active participation of rural women in cooperative programme activities is a driving force that brings women together, so as to improve their quality of life and enhance community development (Ekong,2013).

In this paper, community development is a process that involves community members participating actively in their own affairs, and enabling them to contribute meaningfully in the cultural, political and socio-economic growth of their communities. Hence, the rural women's active participation in cooperative programme activities empower them to fit into the dynamism of the modern society. Therefore, the view of this paper focuses on the revitalization of cooperative programme activities through active participation of rural women for self accomplishment and satisfaction towards enhancing community development. For better understanding and clarification of the subject of this discourse, efforts were made to get the views of scholars on the main concepts of this paper.

\section{COMMUnity DeVElopment}

Community development is a combination of two distinct variables, 'Community' and 'Development'. Primarily, a community is an association of individuals who live in a locality and are guided by norms, religion, values, customs, identity and mutual interest. It is this mutual interest that binds people of the same group to share a common geographical area. Tonnies as cited in Mondal (n.d) viewed community as a normal living social group where people are bound together with a mutual relationship generated through daily contacts within the comprehensive scope of human activities. Medina (2018) posited that a community is a group of people that lives in the same place, sharing certain attitudes and interest in common.

From the point of view of Frazer (2000), a community is a set of values that brings elements of solidarity, commitment, mutuality, self-help, communality and trust among the people. Community as a concept can be approached in terms of its descriptive category or as a set of variables.

\section{These variables include:}

1. Community as a place: According to Ramsey \& Beesley (2007), Territorial or place community is a community of people who are held together because of their common locality or place of work or where they spend most of their time.

2. Community as an interest: According to Henri \& Pudelko (2003), a community of interest is a community of people who come together for a common interest and share a common characteristics.

3. Community as a communion: This means a community that share the same ideology, have a sense of attachment to a particular place or group,without actually residing in a particular area. Such include the religions communities, education communities among others. This implies that community is defined in terms of common interest, belongings, attachments and affiliation of community members. This entails that communities can be urban, suburban and rural respectively.

In this study, community is defined as a group of people who resides in a given locality with common identity, interests, norms, cultural traits and willingly pursuing a common goal for the development of their community.

Development means an improvement in the quality of life through conscious process. It is associated with growth, progress, positive change, empowerment, betterment and capacity building. According to Israel (2018), development is a procedure that creates growth, progress, social, economic, physical, environmental and positive change. This positive change removes inequality, poverty and increase the material welfare of the people through access to education, health and housing. In this regard, there is need to allow necessary changes to take place, so that people could have the amenities and facilities they deserve. The more people develop themselves, the more they would become instrument for further changes. Therefore, development in the context of this study, is a continuous process whereby resources both human and material are utilized for the purpose of community development.

Community development is believed to be a major strategy for rapid development, particularly at the grass root level. In other words, it embraces all efforts towards the advancement of community interest and growth, thus enabling one to contribute significantly to material progress. Hence, the importance of community development in the growth of any nation cannot be over-emphasized.

The United Nations (2014) defines community development as, "a process where community members gather to take collective action and generate solutions to common problems". In the same vein, Kularatne cited in UKEssays (2017), defines community development as improving the living standard of people and expanding their abilities to make their own futures 
through enhancing their welfare. This implies that community development produces a feeling of acceptance and open more potentials for individuals to develop as a team. In another dimension, SCDC (2019), views community development as a way of guiding people to take measures on issues that concerns them. This shows that community development is rooted in the belief that all people should have access to health, well being, justice and opportunity.

Furthermore, Owamalam (2010) enumerated the objectives of community development to include:

- Enhancement of life at the local level through resources (human and material).

- To spread an even living condition in the community in other to avoid neglect of any aspect of living.

- To bring about innovation in the physical and human processes of change.

- $\quad$ To reduce unemployment and abject poverty, provide governmental services and use any creative, technical and accessible assistance outside the community.

- To aim at agricultural development and extension, health programmes \& disease control, rural industrial disinfection, rural education planning and planning for rural funds, development of communication and other recreation facilities. It is necessary to point out that community development in this context empowers the rural dwellers, especially the rural women.

Rural women who engage in subsistence farming, petty trading, artisans crafts seem to be voiceless in their communities. They are usually illiterates and lack access to formal education, finance and infrastructural facilities as observed by (Alosede cited in Ugwunnadi,2014). These barriers make these rural women to contribute insignificantly to decisions that affect their lives and future. Amadi (2017) noted that the goals of National Policy on Women (2000), National Gender Policy (2006) and National Gender Policy Strategic Implementation Plan (2008) is aimed at empowering men and women and achieving gender equality that will eventually lead to development and elimination of poverty. Yet, these women still wallow in abject poverty and ignorance which affects their political status. Regrettably, Kumar (2018), noted that women are still faced with challenges in their political participation worldwide in this $21^{\text {st }}$ century. This shows that women are under-represented and removed at the decision-making levels. Hence, there is urgent need to involve women at the decision-making stage, as it will improve their status, through active participation in cooperative programmes activities.

The essence of participation is exercising voice and choice. When people participate actively in their own affairs, it leads to empowerment, self reliance, economic sustainability and development of leadership skills. Thus, participation of rural women in cooperative programmes involve self help, democracy and equity. According to Cleaveir (2001), participation is a process during which individuals, groups and organizations are given the opportunity to become actively involved in programmes of development. Jamadar (2018) stated that participation is the extent through which beneficiaries were involved in information sharing, negotiation, discussion, decision makings and initiating actions in the programme activities. In line with the notion of
Jamadar, Osuji (as cited in Adekola, 2010), stressing on the components of participation noted that sharing of decision making, its execution, monitoring and appraisal of the needs identification of programmes revives and optimizes the benefits of rural women in their involvement of the programme activities. In other words, participation has a lot of benefits to the participants. As a vital factor, benefits are the main criterion for the recipients of the programme. Once the recipients start receiving benefits from the programme, the participation in the activities becomes enhanced.

Strategies For Revitalizing Cooperative Programmes For Active Participation Of Rural Women Towards Enhancing Community Development.

The following strategies can be utilized in revitalizing cooperative programmes for active participation of rural women towards enhancing community development.

a) Agricultural Cooperative Programme Activities:- The usefulness and importance of agricultural cooperatives cannot be overemphasized. Akinwumi and Abdulahi (2000), observed that rural women formed the highest membership in agricultural cooperatives in Nigeria, because they are virtually found in every village in all the rural communities. Although, agriculture is the backbone of rural economy of every nation, it is mostly carried out by rural women ranging from raising small scale livestock such as goats, sheep, poultry, growing of economic trees, fruits \& vegetables. Other activities include rice farming, cassava processing, oil palm processing and palm kernel oil extraction, among others. All these activities are geared towards increased food production, its availability and affordability. Okeme and Akpama (2018), opined that rural women are known for their hard work, they make foods available and cheaper in order to reduce hunger, malnutrition, extreme poverty and build a healthy generation. Agricultural cooperative as an economic enterprise empowers the rural women so that they can be able to buy improved seedlings, new farm implement, pesticides and fertilizers at reduced prices. Moreso, rural women who belong to agricultural cooperatives are taught by agricultural extension workers on new improved methods of farming, in order to get them acquainted with knowledge of plant pests and disease control, new method of fertilizer application for soil fertility so as to boost their crop yield. All these improved methods of farming will enhance the rural women's production for both subsistence and commercial use. Also, the agricultural cooperative programme creates employment opportunities for women, men and the youths in the rural areas. This will increase their income level, enhance their status and reduce poverty.

b) Thrift and credit cooperative programme activities:Is an entrepreneurial activity that can be carried out in all sectors of the economy. Its members include small scale farmers, traders, craftsmen and women, workers of the same occupation and market women. Adekunle and Henson (2007), observed that thrift and credit cooperative programme activities mobilize local savings 
and administer credit to members. Otto \& Ukpere (2011), noted that thrift \& credit cooperative is one of the distinct cooperatives that are known globally especially in Nigeria, because it mobilizes local savings and enhances the income generating activities of the rural women. As a cooperative programme activity that creates employment opportunities particularly in the rural communities, Akereke and Adekunmbi (2017) observed that thrift and credit allows disadvantaged groups to be organized for social and economic benefits. Such socioeconomic benefits will enhance their economic activities, thereby making them to become self-reliant, selfesteemed and economic independence.

c) Cooperative education programme activities:- In this study, cooperative education programmes can be defined as a purposeful effort that is aimed at imparting quality education and training to rural women in order to reposition and enhance their knowledge, skills and competencies. This means that, quality education and training offers a relaxed environment for capacity building in conjunction with literacy, vocational, entrepreneurial and life skills. Literacy, vocational, entrepreneurial and life skills are embedded in cooperative education. According to Uchendu (2002), cooperative education aims at organizing literacy programmes, developing skills through organized vocational training and developing leadership qualities among members. This implies that through cooperative education, members will understand the principles of cooperatives which will enable them to solve their social and economic challenges in order to become selfreliance. The cooperative principles include among others, establishment of learning/training centres, teaching using interactive skills, providing equal opportunities for participants and exchanging of ideas among participants in cooperative education programmes. Tchami (2007), observed that cooperative education is a set of practices and methods that are used to make members to be aware of these aforementioned cooperative principles and its usefulness. To increase participants awareness on cooperative issues and community matters, they need to be equipped with appropriate skills and competencies that will help in problem solving, leadership and self-management skills. Acquisition of these skills will boost the rural women's confidence, knowledge and as well make them function better in the society. In other words, cooperative education programme activities can strengthen the capabilities of disadvantaged groups in the community, because it will enable them improve themselves, their families and the community at large. Thus, Cooperative education programme activities if well designed and implemented, will be a potential vehicle for rural development and transformation.

d) Cooperative leadership training:- This is a cooperative programme activities that is geared towards empowering the women for effective leadership in decision-making.
Ebonyi and Jimoh (2002),noted that every cooperative programme depends on its leadership style. This implies that training of both members and executives will enhance the progress of the cooperatives. Such training which includes in-service training, workshops and seminars is geared towards enhancing their leadership and management skills, learning how to communicate clearly, so as to make decisions that will motivate, inspire, show respect for loyalty and trust in the subordinates (Gill,2005). In line with this view, D'Souza (2005) noted that cooperative leadership training prepares and equips women in effective leadership training and decision-making techniques. Thus, cooperative leadership training empowers the rural women and enables them to be politically active. Unfortunately, gender bias, socio-cultural, political, discrimination and other challenges have prevented majority of women from participating in community development planning and decision-making process. These discriminations and other challenges persisting in most parts of the world as observed by ILO (2005), has caused the unsatisfactory representation and participation of women in cooperative leadership.

\section{CHALLENGES THAT HINDER RURAL WOMEN FROM PARTICIPATING IN COOPERATIVE PROGRAMME ACTIVITIES TOWARDS ENHANCING COMMUNITY DEVELOPMENT.}

The challenges facing effective women's participation in cooperative programme activities in the rural areas are as follows: Insufficiency of funds, less access to education and training, Lack of knowledge and sensitization and Existence of some cultural practices.

Firstly, insufficiency of funds limits the rural women's active participation in cooperative programmes. This is because the rural women in the rural areas are the poorest, voiceless and lack certain material possessions, as well as finance. Due to poverty and lack of unemployment opportunities, these women engage in low income generating activities. These low income generating activities cannot assist them to acquire the basic goods and services that can sustain them and their families. Hence, insufficiency of funds experienced by these women weaken their capabilities and opportunities to improve their quality of life and that of their families. This lack of funds experienced by these rural women has always been reported in various works by researchers as a barrier to rural projects (Aremu 2004, Ekong 2007, Ndifon 2012).

Another challenge faced by the rural women is less access to quality education and training. This has been identified as a key barrier to rural women's advancement in cooperative programme. According to Anania \& Rwekaza (2018), the practice has always been the exclusion of members in most of the opportunities for cooperative education and training; while the leadership and management are given priorities in most cases. On the other hand, the education and training for the members are done haphazardly with no formal modalities. In addition, problems of ignorance, illiteracy, poverty, poor communication network, poor sensitization and lack of self-confidence among the rural women 
have contributed to their low participation in cooperative programme activities. This may be attributed to lack of access to suitable information services as observed by (Zaid \& Popoola, 2010, Kamba, 2011 and Ugwunnadi, 2014).

Furthermore, low managerial skills among the leadership and lack of commitments by members who defaulted in loan repayment indicates insincerity and dishonesty. This is seen as a barrier to cooperative programmes which may cause uproar among the members (Gbadeyan, 2000).

Moreso, the existence of some cultural practices denies women their rights to land ownership and inheritance, access to credit facilities and human rights (Nwaura, 2014). Also, Okechukwu \& Ugwumba (2016) observed that family responsibilities and the existence of some cultural practices which demand that a married woman seek prior consent of the husband before joining any form of association have placed a major constraint to rural women's participation in cooperative activities.

\section{THE WAY FORWARD}

To ensure active participation of rural women in cooperative programmes, there is need for extensive public sensitization and enlightenment campaigns, using any traditional media, such as the town criers, town union meetings and village meetings, as vital sources of information. Other valuable sources of information are audio-visual and interpersonal communication which include mass media, radio, television, recorded audio, video programmes, age grade associations, associations of trade, churches, agricultural extension workers and any other creative means that can be used equally in exchange of information among the rural women in the rural communities in Nigeria.

Also, community outreach programmes should be organized by Community Based Organizations, Faith-Based Organizations, Non-Governmental Organizations and Government Agencies through cooperative education programme activities to reduce problems of illiteracy and ignorance. This will enhance the rural women's knowledge, skills and information utilization capacity. Relevant information dissemination will equally enhance the socio-economic and political status of the rural women's active participation in cooperative programmes.

To ensure continuity and expansion on the cooperative skills, cooperative education and training should be learnercentered, that is education and training should be based on the members, because they are leaders-in-making. In addition, leadership and management of cooperatives should not take decisions at the top without consulting the members for review. This implies that transformation in structure is very important for meaningful and productive cooperative programmes in the communities.

The progress or failure of any cooperative programmes depend on its leadership style. Every cooperative should take the training of its members staff and leaders very serious, so as to enhance their performances for the advancement of the cooperatives. This can be done through in-service training to orient and re-orient members, workshops and seminars for cooperative leaders, community leaders, market women leaders and other stakeholders in cooperative society matters. Such training is very necessary, as it is geared towards enhancing the knowledge of leaders on leadership and management skills of cooperative programmes

Government at all levels especially during this Covid-19 pandemic, should support the cooperative programmes by mobilizing to provide relief to rural women. This will encourage them to do more in community based poverty alleviation programmes. Community leaders should encourage more women to participate in this programme in other to increase economic activities at the rural level. Sequel to this, government, nongovernmental organizations and cooperate bodies should provide aids and financial assistance to reduce the problems of inadequate funds and small size loans.

More importantly, existing traditions that do not favour women, that is, the land and property ownership legislation and as well as inheritance should be revisited. Women should no longer be discriminated against in access to land, resources and human rights. This will enable these women to gain more control over life decisions that can improve their status, their families, health and economic independence.

In recognition of the usefulness and importance of cooperative programmes in enhancing the status of rural dwellers, if well implemented and managed with sincere leadership, will take care of abject poverty, unemployment, problems of illiteracy, gender inequality, experienced among the rural women in the rural communities.

\section{CONCLUSION}

This paper has communicated the fact that rural women needs to be revitalized in cooperative programme activities towards enhancing community development. Thus, the usefulness and importance of cooperative programme activities for community development cannot be over emphasized. Undoubtedly, the rural women for whom the programme was meant for and their active participation in this programme will create employment opportunities, increase food production, reduce illiteracy and poverty levels and as well increase their income generating levels. As a productive venture, that offers a sense of belonging, the cooperative programme activities improve the living conditions of the rural women and equip them with appropriate skills and competencies that empowers them to fit into the dynamism of the modern society. Once this is achieved, not only will their status change, rural development and transformation will be enhanced, and maternal mortality rate, unemployment, abject poverty and diseases ravaging the rural women in the rural areas will be drastically reduced.

\section{REFERENCES}

[1] Adekunle \& Henson (2007). The effect of cooperative thrift and credit societies on personal agency belief. A study of entrepreneurs in Osun State,Nigeria. Journal of Agricultural Research vol. 2 (12) pp 678-686.

[2] Agricultural Fisheries and Conservative Department (2019). A simple guide to the formation and registration of cooperative societies and credit unions. Retrieved https://www.afcd.gov.hk>agr.sim.

[3] Akerele, E.O \& Adekumbi, S.A. (2017). Impacts of cooperative Thrift and Credit facilities on members business output in Ogun State, Nigeria. Journal of Agricultural Research. Vol. 7 No. 3, 2018. 
[4] Akinwumi, J.A \& Abdulahi, Y.A. (2002). Cooperative strategy for Nigeria. Paper presented at the national cooperative development policy workshop, Asaba.

[5] Amadi, E.I. (2017). Implementation of Nigeria's national gender policy: An appraisal of empowerment and gender equality programmes and projects in rivers state (2006- 2015). Journal of Political Science and Leadership Research, vol. 3 (1), 2017.

Anania,P. \& Rwekaza, G.C(2018).Cooperative Education and Training as a means to improve performance in cooperative societies. Sumerianz Journal of Social Sciences, vol. 1(2)pp 39-50.

[6] Aremu, M.A. (2004). Small scale enterprises: panacea to poverty in Nigeria. Journal of enterprises development 1(1)1-8.

[7] Cleaveir, L. (2001). Evaluating a new and aspiring Extension Director leadership education programme: Determining outcomes and neededimprovements. Journal of leadership education (on-line),9(1), 17-35.

[8] Deji, P.O.(2007). Entrepreneurship. Dryden Press Series in Entrepreneurship,Hard Cover, Delta.

[9] Dogarawa, A.B. (2008). The role of cooperative societies in economic development. Available at http//llipra.ub.unimuenchen.de/23/6.

[10] D'Souza, A.(2005). Leadership: A trilogy on leadership and effective management, Mumbai: St. Paul's publishers.

[11] Ebonyi, V. \& Jimoh, B.O. (2002). Cooperative movement: A way out of poverty in our society. Kaduna : Prestige Publishers.

[12] Ekong, F.U. (2013). Contributions of Women to national development: Example from Akwa Ibom State. Study home comm. Sci. 2(2); 113-119.

[13] FAO (2011). Women in Agricultural closing the gender gap for development. FAO.

[14] Frazer, E. (2000). The problem of communitarian politics. Unity and Conflict, Oxford: Oxford University Press.

[15] Gills, J.J. (2005). Educating for leadership. In D’Souza (Eds) Leadership. Mumbai: St.Paul's Publishers.

[16] Henri, F. \& Pudelko, B. (2003). Understanding and analyzing activity and learning in virtual communities. Journal of Computer Assisted Learning. 19(4), 474-478.

[17] Ikonne, O. \& Duru, F.A. (2015). Socio-economic aspects of deaths by diseases in Abia Central senatorial zone, Nigeria. Abia Journal of the Humanities and social sciences, 7(1):1-23.

[18] ILO (2005). Leadership training manual for women leaders of cooperatives. Geneva. ILO publication.

[19] Israel, S. (2018). Development is a process that creates growth, progress, positive change. Pears Foundation, www.sid-israel.org.

[20] Jamadar, N. (2018). Conceptual frame work for analyzing people's participation in development. www.seiryo-u.ac.jp>gakkai.

[21] Kumar, P. (2018). Participation of women in politics: Worldwide experience. Retrieved from http://www.researchgate.net/publication /327057539.

[22] Maleko.G and Msuya, R. (2015). Women participation in cooperatives, challenges and prospects: The case of selected Saccos and Amcos in Kilimanjaro and Arusha Regions Tanzania, East Africa. Journal of Business Administration and Education, Vol. 7(1), pp 81-111.
[23] Medina, E.V. (2018). What does community truly mean? Retrieved from akoustudios.com

[24] Mondal, P. (n.d) Community: definitions, bases and changing. Concept of community. www.yourarticlelibrary.com

[25] Ndifon, H.M, Agube, E.I \& Odock, G.N. (2012). Sustainability of agricultural cooperative societies in Nigeria. The case of South-South Zone.Nigeria. Mediterranean Journal of Social Sciences, 3(2),19-25.

[26] Nwaura, E.N. (2014). Gender Equality and development. Land Tenure and gender. Approaches and challenges for strengthening rural women's land right. Women's voice Agency and participation Research series, No. 6.

[27] Okechukwu, E.O \& Ugwumba, C. (2016). Cooperators' perception of Women in Leadership position in gender-mixed cooperative societies. The Anambra State of Nigeria experience. AARJSH Asian Academic Research Journal of Social Science and Humanities.

[28] Okeme, I. \& Akpama, C.B. (2018). Women's participation in Agricultura Cooperative activities and rural development in Cross River State, Nigeria. Journal of Educational System. vol. 2(3),pp 15-21.

[29] Otto, G \& Ukpere, W. (2011). Credit and Thrift cooperatives in Nigeria. A potential source of capital formation and employment. African journal of business management vol. 5 (14) pp 5675-5680.

[30] Owamalam, B.J. (2010). Community Development in Action. London: University Press.

[31] Scottish Community Development Centre (2019). What is community development? Retrieved from https://www.scdc.org.uk>who.

[32] Tchami, G. (2007). Hand book on cooperatives for use of workers organizations. International Labour Office (ILO) Geneva, Switzerland.

[33] Uchendu, S.O. (2002). Cooperative Education: A fundamental approach. Akwa Ibom: Amibros Printers.

[34] Ugwunnadi, C.M. (2014). Information needs and access to rural women for community development in Enugu North Senatorial Zone of Enugu State. (M.SC Thesis) Department of Library Information Science, University of Nigeria Nsukka.

[35] Uhegbu,A.N.,Unagha,A.O\&Amaechi,N.M(2017).Participation of women in cooperative activities in Imo State, Nigeria. The information science studies. Vol. 3(2), pp1-12.7.

[36] UKEssays (2018). The definitions of community development. Retrieved https://www.ukessays.com/essays/education/the-different-definitions.

[37] United Nations Development Programme (2014). Community Development. Retrieved from https://en.m.wikipedia.org>wiki.

[38] UN Women Organization Watch (2019). The role of women in rura development, food production and poverty eradication. https://www.unwomen.org>in-focus.

\section{AUTHORS}

First Author - Dr. Blessing Chinyere Elekwa

Email: elekwa.blessing@gmail.com 